\title{
Soil Erosion Prediction Using GIS and Remote Sensing on Manjunto Watershed Bengkulu-Indonesia
}

\author{
Gusta Gunawan $^{1}$, Dwita Sutjiningsih ${ }^{2}$, Herr Soeryantono $^{2}$ and Soelistiyoweni Widjanarko ${ }^{2}$ \\ ${ }^{1}$ Department of Civil Engineering, Faculty of Engineering, University of Bengkulu, Jl. W.R. Supratman No.1 \\ Bengkulu 38371, Indonesia, e-mail: gustagunawan@yahoo.com \\ ${ }^{2}$ Department Civil and Environmental Engineering, Faculty of Engineering, University of Indonesia, Depok, \\ West Java 16424, Indonesia. " e-mail: dwita@eng.ui.ac.id, ${ }^{* *} e$-mail: herr.soeryantono @ ui.ac.id
}

Received 16 January 2012 / accepted 2 January 2013

\begin{abstract}
The study aimed to assess the rate of erosion that occurred in Manjunto Watershed and financial loss using Geographic Information System and Remote Sensing. Model used to determine the erosion is E30 models. The basis for the development of this model is to integrate with the slope of the slope between (NDVI). The value of NDVI was obtained from satellite imagery. Slope factor obtained through the (DEM) processing. To determine the amount of economic losses caused by erosion used the shadow prices. The amount of nutrients lost was converted to fertilizer price. The results showed that the eroded catchment area had increased significantly. The rate of average annual erosion in the watershed Manjunto in 2000 was amounted to $3 \mathrm{Mg} \mathrm{ha}^{-1} \mathrm{yr}^{-1}$. The average of annual erosion rate in the watershed Manjunto increased $27 \mathrm{Mg} \mathrm{ha}^{-1} \mathrm{yr}^{-1}$ in the year 2009. Economic losses due to erosion in 2009 was Rp200,000,- for one hectare. Total losses due to erosion for the total watershed area was Rp15,918,213,133, - . The main factor causing the high rate of erosion was high rainfall, slope and how to grow crops that did not pay attention to the rules of conservation.
\end{abstract}

Keywords: Digital elevation model, GIS, remote sensing, soil erosion, valuation erosion

\section{INTRODUCTION}

Changes in land use and deforestation have caused increasing of soil erosion from year to year. High rate of soil erosion caused adverse impacts on environmental and economic aspects ( $\mathrm{Lal}$ 1998) and it could even spread to the social aspect (Ande et al. 2009). This is because erosion can reduce the storage capacity of a lake or reservoir (Clark et al.2003), lowering the quality of river water (Ananda and Herath 2003; Lal 1998; Pimentel et al.1995), and wash the nutrients needed by plants (Ande $e t$ al.2009).

Soil erosion is a natural process that slough off and land transport material through the action of erosive agents such as water, wind, gravity, and human disturbance (Lal 2001). However, if soil erosion is occurring faster than necessary, then it will have a negative impact on the environment, economic and social. Strategic effort to reduce the negative impacts of soil erosion is to conduct soil and water conservation measures intensively. The complete spatial data is requirements to support these activities in the planning, monitoring and

J Trop Soils, Vol. 18, No. 2, 2013: 141-148

ISSN 0852-257X evaluation (Hazarika and Honda 2001; Ande et al. 2009). The data must be accurate, do not require high cost and is collected in the long time process (Green 1992; Morgan 2005). One of the urgent data is a map of soil erosion to evaluate the economic losses caused by erosion. Map of soil erosion can include erosion risk map or maps of erosion (Arsyad 2010). Erosion risk maps are useful for land use planning, while the erosion map is useful for planning erosion control or reclamation of barren land.

Rapid development occurring in the technology of Remote Sensing (RS) and Geographic Information Systems (GIS) provide a new approach to meet various demands related to resource modeling (Mermut and Eswaran 2001; Salehi et al.2003) including soil and water conservation activities (Hazarika et al. 2009). RS in the GIS database integration can reduce costs, time, and improve the information detailed soil surveys for various purposes (Green, 1992). Satellite data can be used for mapping, monitoring and estimation of soil erosion (Hazarika and Honda 2001). Several studies demonstrate the potential utility of RS and GIS to assess quantitatively the level of soil erosion (Saha et al.1991; Saha and Pande 1993; Mongkosawat et al. 1994).

Some researchs conducted in various countries use GIS and RS to assess the soil erosion. Some of 
the researchers who conducted the study on erosion in other countries is Hazarika and Honda (2001), mapping the threat of soil erosion in the catchment area of Northern Thailand Ao Mae. Ande et al.(2009) using the approach to estimating erosion Morgan and Finney model (MMF) in Southwestern Nigeria. Kefi and Yoshino (2010) assessed the risk of erosion on agricultural productivity using RUSLE, remote sensing and GIS in a catchment area in Tunisia.

However, erosion mapping using GIS and RS in Indonesia have not been conducted intensively (Arsyad 2010), especially in areas outside Java. Arsyad stated (2010), that the only result of soil erosion map, published was the mapping performed by Dames (1955) using traditional methods in the river flow strip (DAS) of Central Java. In Indonesia, application of GIS to evaluate land degradation first was performed by Lanya (1996). Rate of erosion has done by identifying morphological changes in the soil in situ.
The purpose of this research was to evaluate the risk of erosion occurring in the watershed area Manjunto-Bengkulu and its economic losses by using GIS and Remote Sensing. The basis of this model selection is an area of research that is still dominated by forests and to evaluate the erosion traditionally will take a long time and high costs (Hazarika and Honda 2001; Kefi and Yoshino 2010).

\section{MATERIALS AND METHODS}

\section{Study Site}

The research was conducted in the Manjunto watershed. It is located in the District of Mukomuko, Bengkulu Province, Indonesia, at $02^{\circ} 10^{\prime} 30^{\prime \prime}$ $02^{\circ} 30^{\prime} 15^{\prime \prime}$ South Latitude and 101 5'30" $107^{\circ} 35^{\prime} 00^{\prime \prime}$ East Longitude. Manjunto watershed area that was dominated by forests, watershed area was 79,581 ha (Figure 1). Based on data from BMG (Meteorological and Geophysical Agency)

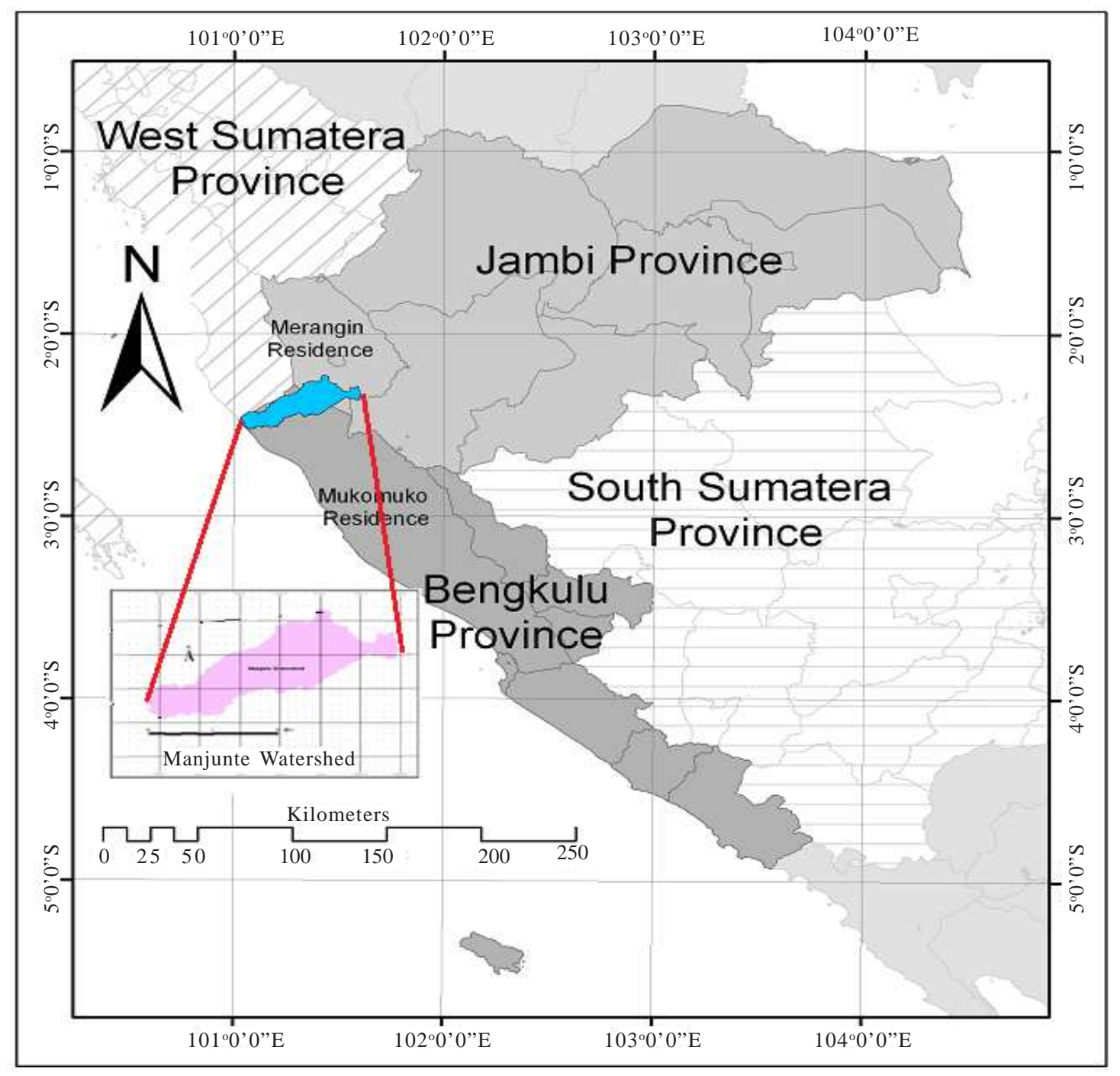

Figure 1. The location of Manjunto Watershed. 
Mukomuko district of Bengkulu province, the average rainfall of the study region was 3,329.70 $\mathrm{mm} \mathrm{yr}^{-1}$ and average annual temperature was 23.0 ${ }^{\circ}$ C. Based on Soil Survey Staff (1998) the most dominant soil type in research site are Endoaquepts, Udifluvents, and Eutrudepts.

\section{Preparation of Soil Map}

Preparation of Soil Map was based on map of land units and land sheet of Sungai Penuh (0813) Sumatra 1:250.000 Scale. Classification of Each soil mapping unit was classified according to the spread of the predominant soil types in quantitative and was grouped into different classes or soil mapping unit.

Slope Principles maps were made by calculating the slope based on the transformation of the difference between the elevation from west to east through the process of reduction (derivation) partially with respect to the $\mathrm{x}$ axis (map $\mathrm{dx}$ ) and the difference between the elevation from north to the south which is a partial decrease in the $y$-axis (the map dy). Data contour lines and elevation points were taken from the DEM (digital elevation model). DEM used as the input DEM Bengkulu area with $30 \mathrm{~m}$ resolution ASTER GDEM was downloaded from version 2. After the interpolation process and change the vector data to raster processed with the help of Arc Gis 9.3, then the slope class was into performed different classes as follows: $0-8 \%$ (flat), $8-15 \%$ (wavy), $15-25 \%$ (hilly), $25-45 \%$ (mountainous) and $>45 \%$ (steep).

Digital Image Processing was used to Produce Land Cover Map. Land cover information was obtained through the interpretation of Landsat 7 ETM path 126/row 062 July 22, 2000 acquisition date and Spot 4 path 355/row 271 May 17, 2009 acquisition date. The steps in the identification way to produce land cover maps are available in Figure 2.

\section{Estimated Erosion with $\mathrm{E}_{30}$ Model}

To estimate the rate of erosion that occured in each soil mapping unit (SMU), the following equation (Hazarika and Honda 2001) is used:

$E=E_{30}\left(S / S_{30}\right)^{0.9}$

Where $\mathrm{E}=$ rate of annual soil erosion in the watershed of Manjuto $\left(\mathrm{Mg} \mathrm{ha}^{-1} \mathrm{yr}^{-1}\right), \mathrm{S}=$ gradient or slope (percent), $\mathrm{S}_{30}=$ Value of Tan $30^{\circ}$ and $\mathrm{E}_{30}$ is the level of erosion that occurs on a slope of $30^{\circ}$. $\mathrm{E}_{30}$ values were obtained from the following equation 2 (Hazarika and Honda 2001):

$$
E_{30}=\exp \left[\left(\frac{L o g E_{\min }-L o g E_{\max }}{N D V I_{\max }-N D V I_{\min }}\right) \cdot\left(N D V I-N D V I_{\min }\right)+L o g E_{\max }\right]
$$

The maximum (Emaks) and minimum (Emin) of erosion values were obtained from the data made by the Public Works Department of Bengkulu

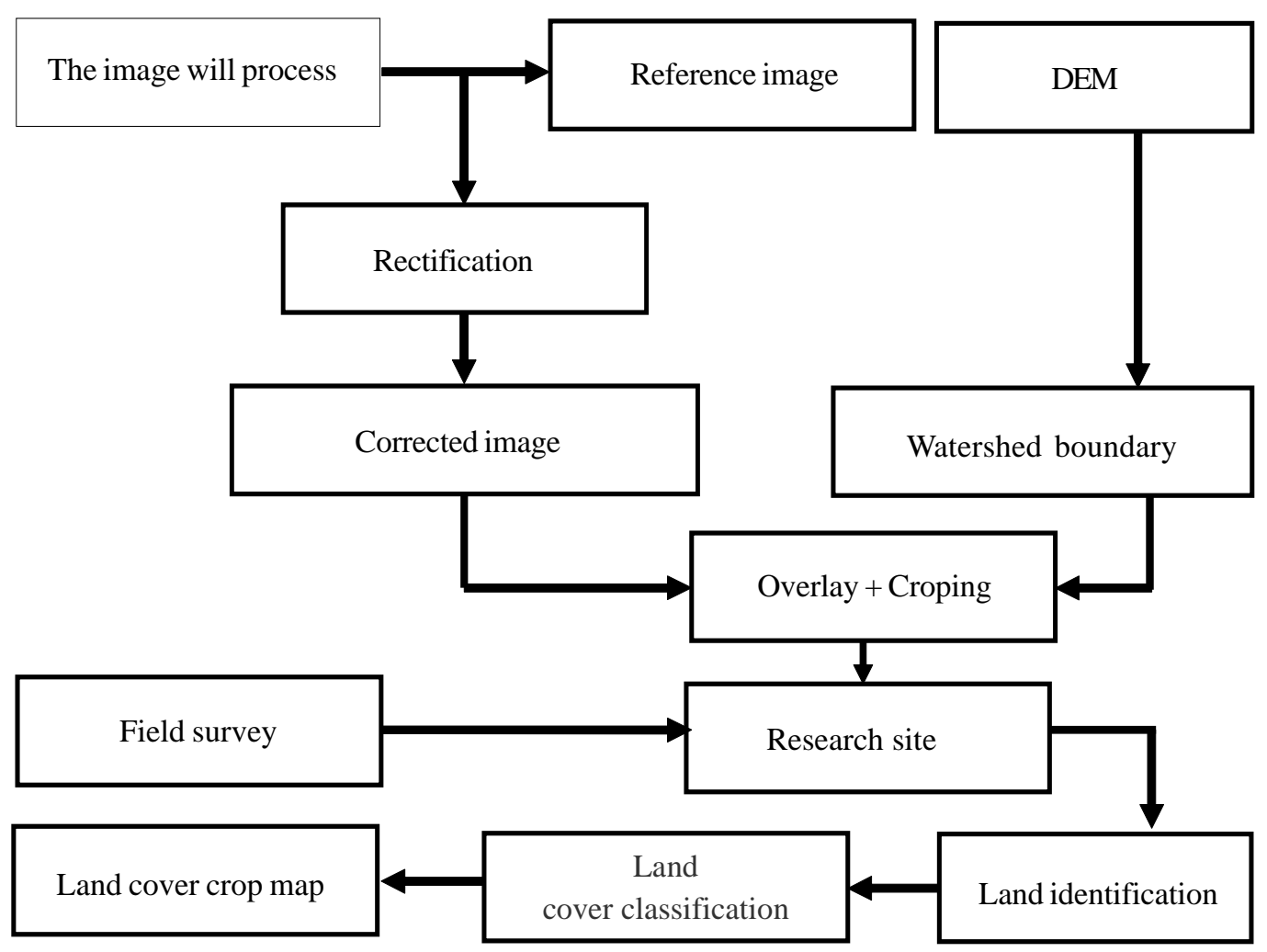

Figure 2. Land cover identification procedures. 
province. The maximum erosion value was $242 \mathrm{Mg}$ ha-1 yr-1 and the minimum erosion value was 0.1 Mg ha-1 yr-1. NDVI (normalized difference vegetation index) was calculated using equation 3. To avoid negative values and facilitate the processing of digital data, NDVI values were obtained from recording image made re-scale (rescale), so the NDVI equation is as follows (Panuju et al. 2009).

$$
N D V I=\left[\left(\frac{B_{4}-B_{3}}{B_{4}+B_{3}}\right)+1\right] x 100
$$

Where NDVI is a vegetation $\times$ index that reflects the level of greenness of vegetation $\times$ condition (Malingreau 1986). Band 4 (B4) and Band 3 (B3) are a channel on satellite images that record the infrared spectral (IR/IR) and near infrared (Near Infra Red/ NIR).

\section{Erosion Valuation}

The valuation methods used to estimate economic losses due soil erosion are presented in Figure 3. The economic losses due to erosion were determined by replacement cost technique (Dixon et al. 1994). Nutrients (N, P, K) were converted with a purchase cost of fertilizers (Urea, SP36, KCl).

\section{RESULTS AND DISCUSSION}

\section{The slope Map}

Slope map of DEM was processed with the help of Arc Gis 9.3 which is presented in Figure 4. Data were processed by GIS contained information on slope and the number of pixels or extensive information. Information about slope is presented in Table 1.

The mayor study site had the slope above $8 \%$. The Slope factor will influence the speed and volume of surface runoff. Small slope will provide more opportunities the rain water to infiltration so that runoff volume will reduce. In the other side, a low percentage of slope will reduce runoff velocity so that its ability to erode and transport the soil will be small.

Table 1. The slope of the Manjunto Watershed.

\begin{tabular}{lrrc}
\hline $\begin{array}{l}\text { Slopes } \\
(\%)\end{array}$ & Pixel number & Area (ha) & $\begin{array}{c}\text { Percentages } \\
(\%)\end{array}$ \\
\hline $0-8$ & $229,478.90$ & $20,923.887$ & 26.292 \\
$8-15$ & $350,398.70$ & $31,949.351$ & 40.147 \\
$15-25$ & $166,219.00$ & $15,155.848$ & 19.045 \\
$25-45$ & $62,160.86$ & $5,667.827$ & 7.122 \\
$>45$ & $64,529.12$ & $5,883.765$ & 7.393 \\
\hline Total & $872,786.60$ & $79,580.678$ & 100.000 \\
\hline
\end{tabular}

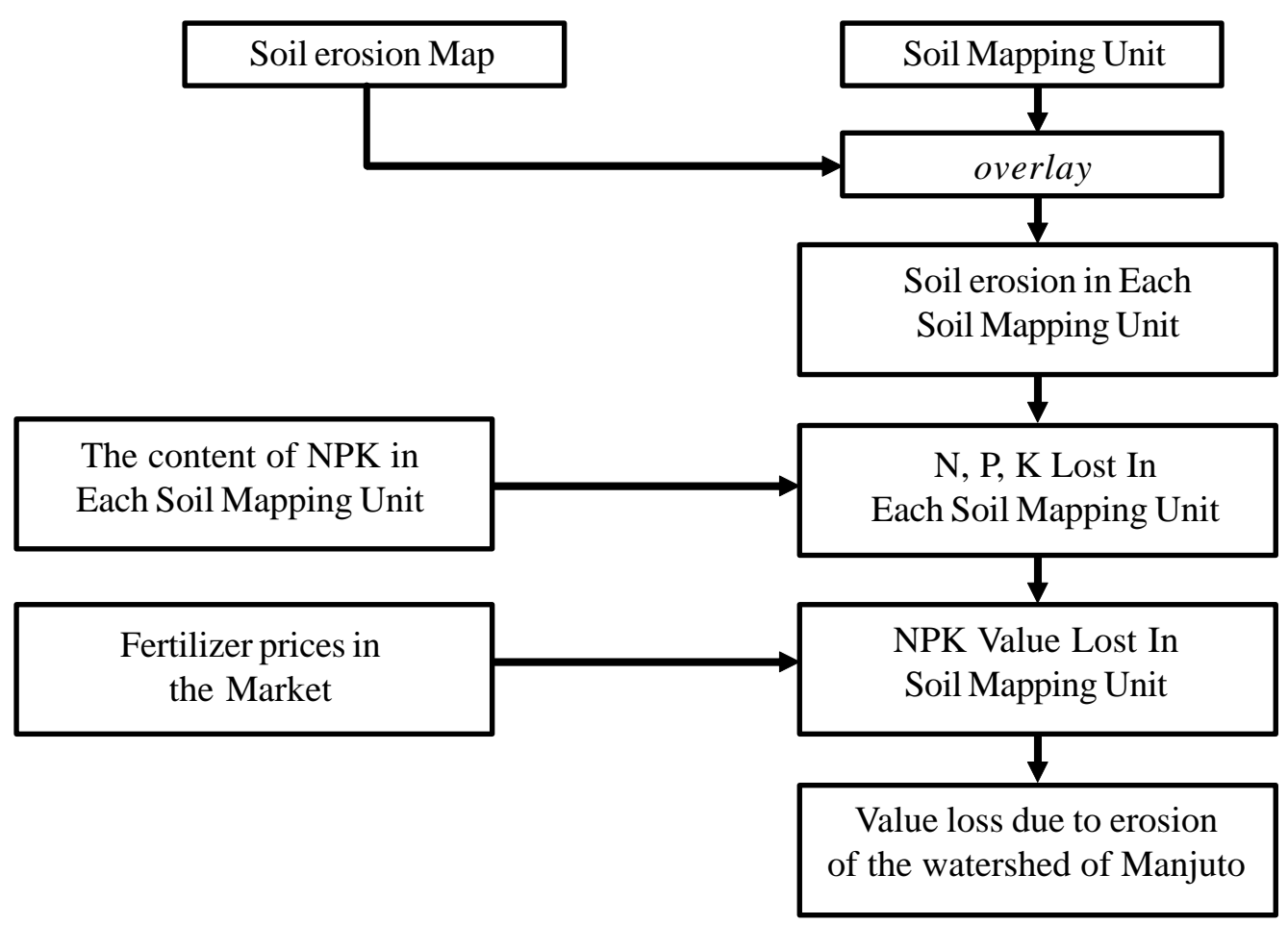

Figure 3. The steps of erosion valuation to estimate economic losses. 


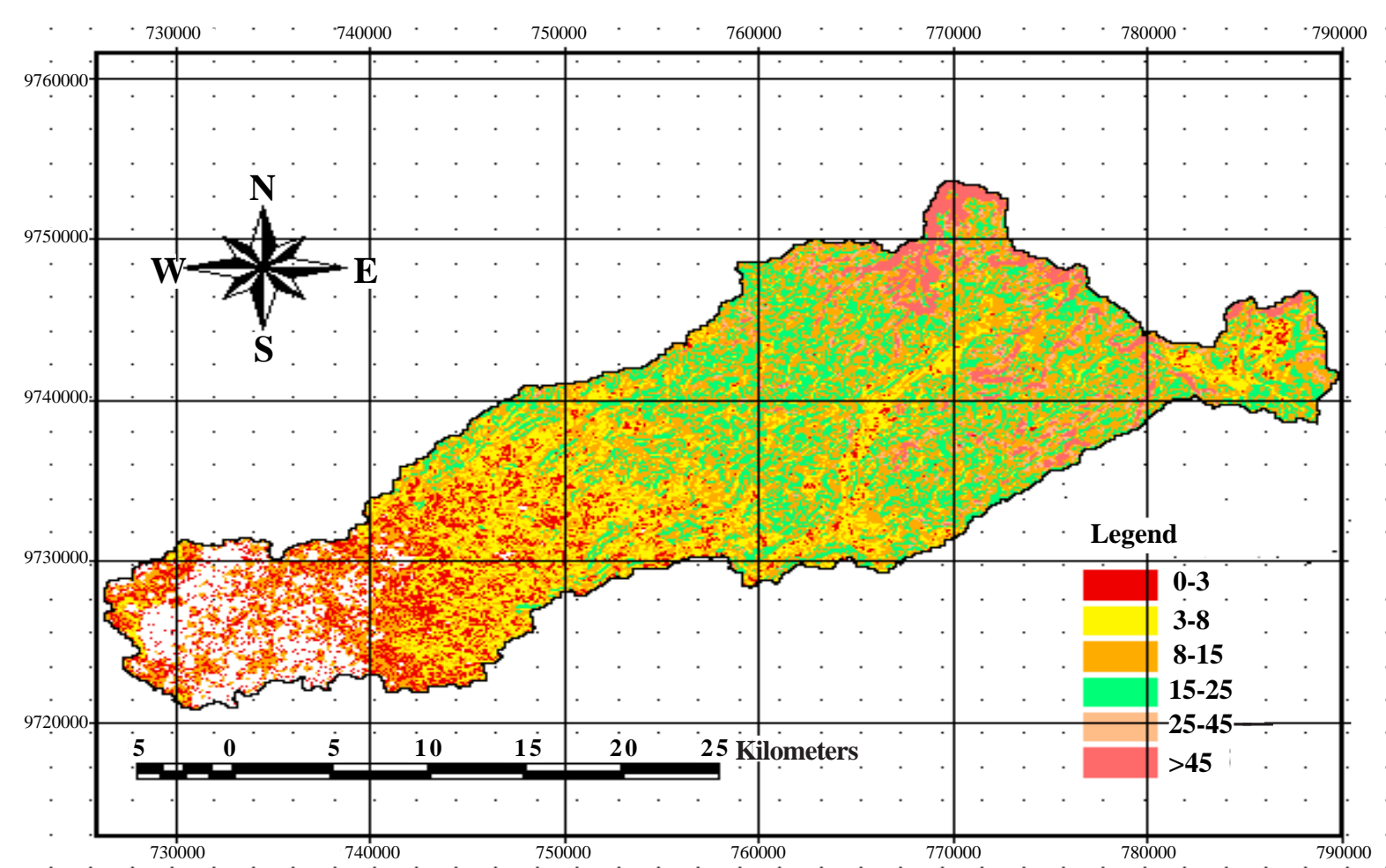

Figure 4. The slope map of Manjunto Watershed.

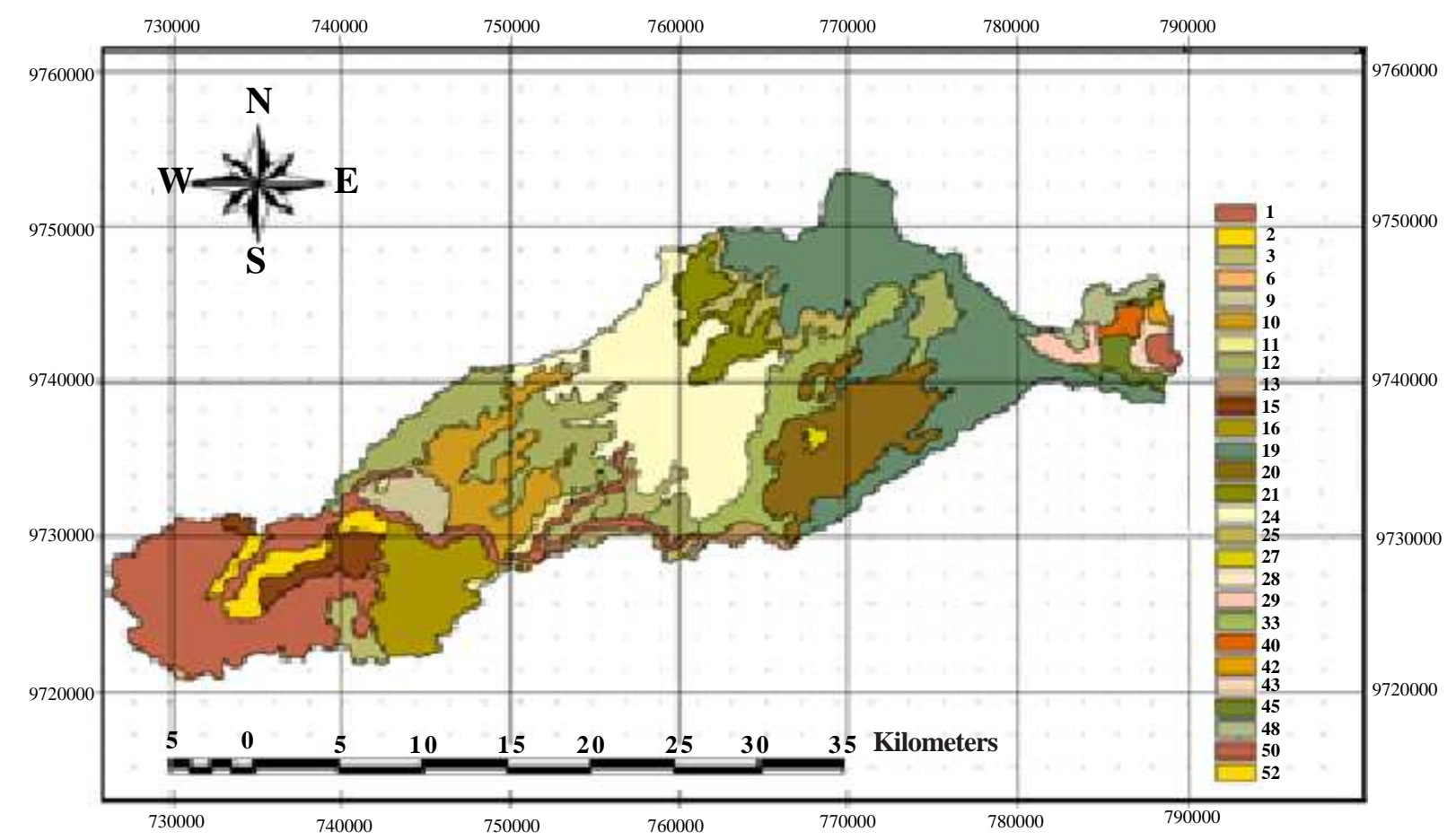

Figure 4. Soil map of Manjunto Watershed.

\section{Soil Map Unit}

The results of the identification of classes of each unit of land by the spread of the dominant soil types are presented quantitatively in Figure 5.

From the preparation of soil map units, the dominant soil types at the study site are known
Endoaquepts, Udifluvents, and Eutrudepts with the proportion of each land unit varied.

\section{Land Cover Identification}

Based on the identification of land cover in 2000 and 2009, the conversion of land use and the reduction of forest from deforestation were shown. 


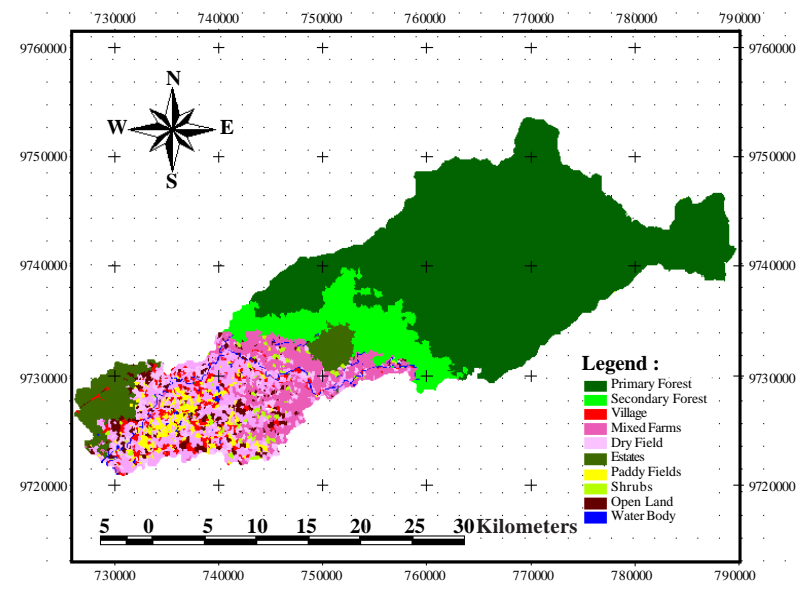

(A)

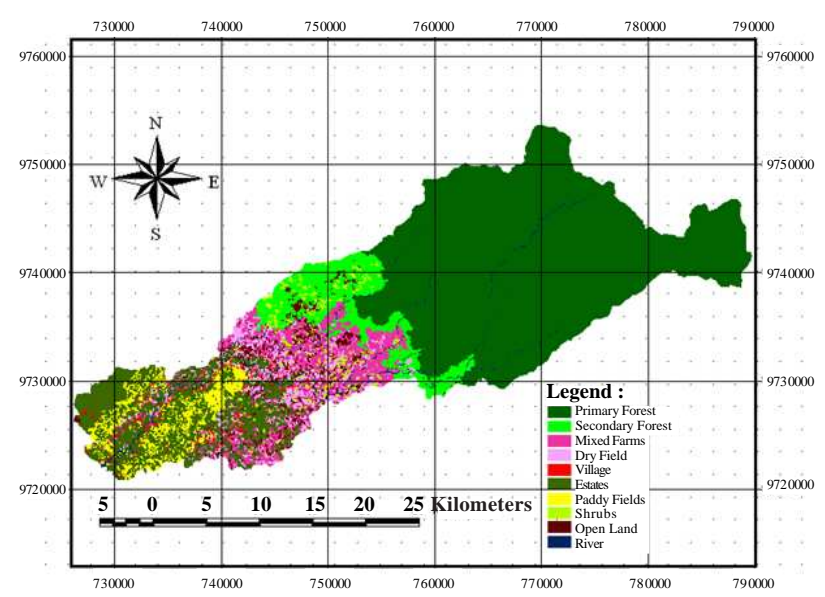

(B)

Figure 6. Land cover map in the year 2000 (A) and 2009 (B).

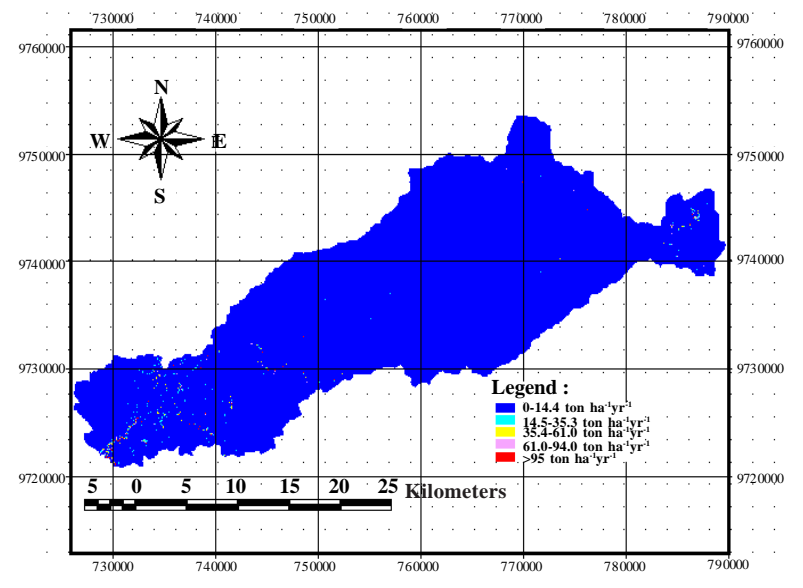

(A)

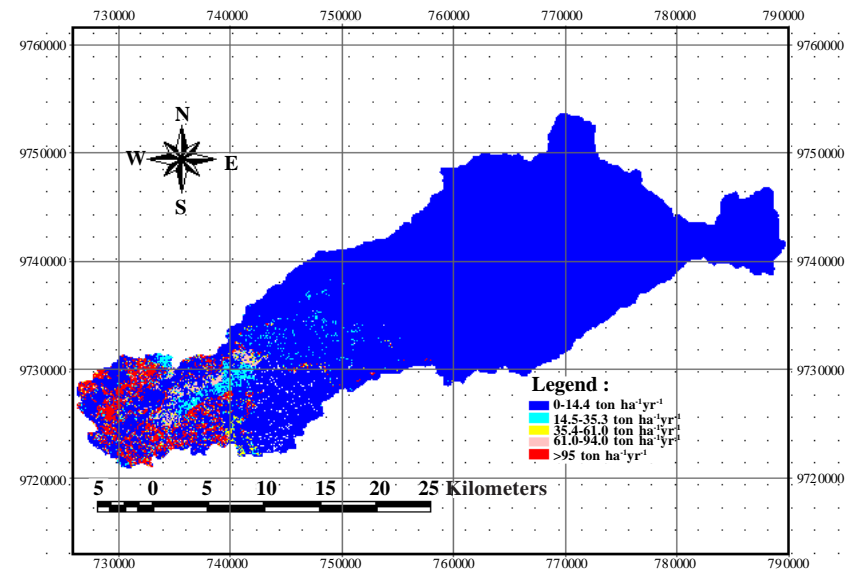

(B)

Figure 7. Map of average annual erosion in the year 2000 (A) and 2009 (B).

Land cover changed on every class of land uses are shown in Figure 6. The total area of forest significantly reduced, while the plantation or estates area increased significantly. Changes in land use were influenced by the local livelihoods which were the majority as a farmer.

\section{Soil Erosion Mapping}

The value of soil erosion that occured at each pixel based on the calculation results by using equation 1 is presented in the form of annual rate soil erosion maps (Figure 7).

Eroded watershed area increased when compared to conditions in 2000. Total amount of lost land in the watershed Manjunto in 2000 was at $1,399,209 \mathrm{Mg}$ and in 2009 amounted to 23,004,391 $\mathrm{Mg}$ (Figure 7). Erosion rate of the annual average in 2000 was $3 \mathrm{Mg} \mathrm{ha}^{-1} \mathrm{yr}^{-1}$, and in 2009 was $27 \mathrm{Mg}$ $\mathrm{ha}^{-1} \mathrm{yr}^{-1}$. High erosion was occured in the lower reaches of the basin's land use types, namely Field / moor. Factors causing the high rate of erosion are a way of farming that pays little attention to the rules of conservation and high rainfall.

\section{Economic Loss Due to Erosion}

To know the economic losses resulting from soil erosion, stacking overlap between the maps of erosion with soil map units that have attribute values of nutrient was carried out content $(\mathrm{N}, \mathrm{P}$ and $\mathrm{K})$ on each Soil mapping unit. The results showed that the amount of nutrients loss $(\mathrm{N}, \mathrm{P}, \mathrm{K})$ on average for 1 hectare of land were : $13 \mathrm{~kg} \mathrm{ha}^{-1}, 1.54 \mathrm{~kg}$ $\mathrm{ha}^{-1}, 10.1 \mathrm{~kg} \mathrm{ha}^{-1}$ respectively. If the fertilizer price of urea was Rp2,500 kg-1, TSP was Rp2,400 $\mathrm{kg}^{-1}$ and $\mathrm{KCL}$ was $\mathrm{Rp} 7,000 \mathrm{~kg}^{-1}$, so the economic losses that occured in the watershed Manjunto during 2009 amounted to USD 200,000 ha-1. Number of losses for the entire watershed area was 
Rp15,918,213,133,-. Losses due to erosion at the study site were high when compared with other countries.

\section{CONCLUSIONS}

Based on the analysis of erosion evaluations which were conducted in year 2000 and 2009, some conclusions were obtained. The total area of the eroded basin had increased significantly from year to year. Total amount of soil lost by erosion in the watershed of Manjunto in 2000 amounted to $1,399,209 \mathrm{Mg}$ and in 2009 increased to 23,004,391 $\mathrm{Mg}$. The average erosion rate in 2000 was $3 \mathrm{Mg}$ $\mathrm{ha}^{-1} \mathrm{yr}^{-1}$ and in 2009 increased to $27 \mathrm{Mg} \mathrm{ha}^{-1}$ $\mathrm{yr}^{-1}$. Economic losses that occured in the watershed of Manjunto during 2009 amounted to USD 200,000 $\mathrm{ha}^{-1}$ and the total losses amounted to Rp15,918,213,133, -.

\section{ACKNOWLEDGEMENTS}

We wish to thank the Institute of Space and Aeronautics Chairman for his help in providing data for this study. We also wish to thank the Head of the Faculty of Engineering, University of Indonesia. This paper is part of the Doctoral Dissertation Research in Faculty of Engineering, University of Indonesia.

\section{REFERENCES}

Aksoy E, G Ozsoy and MS Dirim. 2009. Soil mapping approach in GIS using Landsat satellite imagery and DEM data. Afr J Agric Res 4: 1295-1302.

Ananda J and G Herath. 2003. Soil erosion in developing countries: a socio-economic appraisal. J Environ Manage 68: 343-353.

Ananda J, G Herath and A Chisholm. 2001. Determination of yield and Erosion Damage Functions Using Subjectivly Elicited Data: application to Smallholder Tea in Sri Lanka. Aust J Agric Resour Ec 45: 275-289.

Ande OT, Y Alaga and GA Oluwatosin. 2009. Soil erosion prediction using MMF model on highly dissected hilly terrain of Ekiti environs in southwestern Nigeria. Int J Phys Sci 4: 053-057.

Arnold JG, BAEngel and R Srinivasan. 1998. A continuous time grid cell watershed model. Proc. of application of Advanced Technology for management of Natural Resources.

Arsyad S. 2010. Konservasi Tanah dan Air. IPB Press. Bogor-Indonesia (in Indonesian).

Asdak C.1995. Hydrology and Watershed Management. Gadjah Mada University Press, Yogyakarta.

Barlin RD and ID Moore. 1994. Role of buffer strips in management of waterway pollution: a review. Environ Manage 18: 543-58.
Brough PA.1986. Principle of Geographical Information Systems For Land Resources Assessment. Oxford University Press, 194p.

Clark B and J Wallace. 2003. Global connections: Canadian and world issues. Toronto, Canada: Pearson Education Canada, Inc.

Cochrane T A and DC Flanagan. 1999. Assessing water erosion in small watershed using WEPP with GIS and digital elevation models. J Soil Water Conserv 54: 678685 .

Dames TWg. 1955. The Soils of East Central Java; with a Soil Map 1:250,000. Balai Besar Penjelidikan Pertanian, Bogor, Indonesia.

Dixon JA, LF Scura, RA Carpenter and PB Sherman. 2004. Economic Analysis of Environmental Impacts $2^{\text {nd }}$ ed. Eartscans Publication Ltd., London.

Fistikoglu O and NB Harmancioglu. 2002. Integration of GIS with USLE in Assessment of Soil Erosion. Water Resour Manage 16: 447-467.

Green K. 1992. Spatial imagery and GIS: integrated data for natural resource management. J Forest 90: 32-36.

Hazarika MK and H Honda. 2001. Estimation of Soil Erosion Using Remote Sensing and GIS, Its Valuation \& Economic Implications on Agricultural Productions. The $10_{\text {th }}$ International Soil Conservation Organization Meeting at Purdue University and the USDA-ARS Soil Erosion Research Laboratory.

Hazarika S, R Parkinson, R Bol, L Dixon, P Russell, S Donovan and D Allen. 2009. Effect of tillage system and straw management on organic matter dynamics. Agron Sustain Develop 29: 525-533. doi: 10.1051/ agro/2009024.

Honda KL, A Samarakoon, Y Ishibashi, Mabuchi and S Miyajima.1996. Remote Sensing and GIS technologies for denudation estimation in Siwalik watershed of Nepal,p. B21-B26. Proc. 17 ${ }^{\text {th }}$ Asian Conference on Remote Sensing, Colombo, Sri lanka.

Kefi M and K Yoshino. 2010. Evaluation of The Economic Effects of Soil Erosion Risk on Agricultural Productivity Using Remote Sensing: Case of Watershed in Tunisia. International Archives of the Photogrammetry, Remote Sensing and Spatial Information Science, Volume XXXVIII, Part 8, Kyoto Japan.

Kefi M, K Yoshino, K Zayani and H Isoda. 2009. Estimation of soil loss by using combination of Erosion Model and GIS: case of study watersheds in Tunisia. J Arid Land Stud 19: 287-290.

Lal R. 1998. Soil erosion impact on agronomic productivity and environment quality: Critical Review. Plant Sci 17:319-464.

Lal. 2001. Soil Degradation by Erosion. Land Degrad Develop 12: 519-539.

Lanya I. 1996. Evaluasi Kualitas lahan dan Produktivitas Lahan Kering Terdegradasi di Daerah Transmigrasi WPP VII Rengat Kabupaten Indragiri Hulu, Riau. [Disertasi Doktor]. Program Pasca Sarjana IPB, Bogor (in Indonesian). 
Mermut AR and H Eswaran. 2001. Some major developments in soil science since the mid 1960s. Geoderma 100: 403-426.

Mongkolsawat C, P Thurangoon and Sriwongsa.1994. Soil erosion mapping with USLE and GIS. Proc. Asian Conf. Rem. Sens., C-1-1 to C-1-6.

Morgan RPC, Morgan DDV and Finney HJ. 1984. A predictive model for the assessment of erosion risk. J Agric Eng Res 30: 245-253.

Morgan RPC. 2005. Soil Erosion and Conservation. 3rd ed. Malden, MA: Blackwell Publishing Co.

Panuju DR, F Heidina, BH Trisasongko, B Tjahjono, A Kasno, AHA Syafril. 2009. Variasi nilai indeks vegetasi MODIS pada siklus pertumbuhan padi. J.Ilmiah Geomat. 15, 9-16 (in Indonesian).

Pimentel D, C Harvey, P Resosudarmo, K. Sinclair, D Kurz, M Mc Nair, S Christ, L Shpritz, L Fitton, R Saffouri and R Balir. 1995. Environmental and Economic
Costs of Soil Erosion and Conservation Benefits. Science 267: 1117-1123.

Saha SK and LM Pande. 1993. Integrated approach towards soil erosion inventory for environmental conservation using satellite and agrometeorological data. Asia Pac Rem Sens J 5: 21-28.

Saha SK, Kudrat M and Bhan SK.1991. Erosional soil loss prediction using digital satellitee data and USLE. In: S Murai (ed). Applications of Remote Sensing in Asia and Oceania - Environmental Change Monitoring. Asian Association of Remote Sensing, pp. 369-372.

Salehi MH, Eghbal MK and Khademi H. 2003. Comparison of soil variability in a detailed and a reconnaissance soil map in central Iran. Geoderma 111: 45-56.

Soil Survey Staff. 1998. Keys to Soil Taxonomy. Eighth Edition. United States Department of Agriculture Natural Resources Conservation Service. Washington, D.C. 